\title{
Lean Concept in Small and Medium Enterprises
}

\section{Lean koncept v malih in srednjih podjetjih}

\author{
Zorana Tanasić1,*, Goran Janjić1 ${ }^{1}$, Borut Kosec² \\ ${ }^{1}$ University of Banja Luka, Faculty of Mechanical Engineering, Bulevar Vojvode Stepe Stepanovića 71, 78000 Banja Luka, \\ Bosnia and Herzegovina \\ 2 University of Ljubljana, Faculty of Natural Sciences and Engineering, Aškerčeva cesta 12, 1000 Ljubljana, Slovenia \\ *zorana.tanasic@mf.unibl.org
}

\begin{abstract}
The Lean concept is recognisable by how fast innovations are implemented and production processes are improved. Likewise, analysis of the implementation of Lean concepts so far has shown that Lean methods and tools cannot be applied to small and medium enterprises (SMEs) in the same measure as they can be applied to large enterprises.

This paper aims to present a critical review of the implementation of Lean concepts in SMEs with the claim that Lean concept can be successfully applied in all branches of industry, provided that the Lean concept is fully understood, and it's meaning, principles and practice. Given that SMEs have limited resources, they often face difficulties during the implementation of all Lean tools and methods.

Depending on the type of improvement in Kaizen activities, the Poka Yoke and Jidoka tools should be applied. Every improvement in the production process needs to be standardised as soon as possible so that the processes can become more continuous and efficient.
\end{abstract}

Key words: Lean concept, SMEs, Model, Methods, Tools

\section{Povzetek}

Lean koncept je poznan po hitrosti implementacije inovacij in napredovanja procesa proizvodnje. Prav tako kaže analiza dosedanje implementacije Lean koncepta, da Lean metode in orodja niso v enaki meri uporabni $\mathrm{v}$ malih in srednjih podjetjih (MSP) v primerjavi z velikimi.

Cilj tega dela je prikazati kritičen pogled na uporabo Lean koncepta $\mathrm{v}$ malih in srednjih podjetjih ob predpostavki, da se lahko Lean koncept uspešno uporabi v vseh vejah industrije, vendar pod Pogojem da je koncept v popolnosti apliciran oziroma njegov pojem, principi in prakse. Glede na to, da imajo mala in srednja podjetja omejene vire, se pogosto soočajo s težavami pri implementaciji vseh Lean orodij in metod.

V odvisnosti od vrste napredovanja v Kaizen aktivnostih je potrebno uporabiti orodja Poka Yoke in Jidoka. Vsak napredek v proizvodnem procesu je potrebno čimprej standardizirati, da postanejo procesi kontinuirni in učinkovitejši.

Ključne besede: Lean koncept, MSP, Model, Metode, Orodja 


\section{Introduction}

Business processes and the environment in which the business world is located are changing at a high rate due to globalisation, the Internet, e-commerce, and so on. Companies that do not follow these changes in the business remain far behind their competitors. To establish the realistic basis for the development of the company, continuous communication of management as well as the involvement of all stakeholders is needed. The only way to achieve sustained success is to establish an innovative organisation, which is flexible, quickly adapts to changes in the environment and learns quickly. The key to success lies in establishing an organisational culture in which all employees feel not for the obligation but a need for constant innovation and improvement of their own work. By this approach, employees provide for themselves a secure job and survival on the market. The management of production systems is very demanding and is often very unpredictable. The company behaves like a living organism, that is, all processes take place simultaneously with one goal, which is survival along with profit. To successfully manage the production enterprice, it is necessary to integrate human, material and financial resources into efficient systems. This is a major challenge because a full understanding of the system is needed with the ability to anticipate the behaviour of the company's macro environment.

Many agree that Japanese companies are one of the best and most effective companies, but no one explains in detail why and how they have become so successful. The most common explanation is their culture and traditions, but their investments in scientific and technical technological research are emphasised as one of the key aspects of their success in the world market. In this paper, it is intended to present and demonstrate that Lean methods and tools can be applied in small and medium enterprises (SMEs). Also, it should be emphasised that the active participation of the management and well-trained staff may contribute to business environment in which problems are solved; occurrence of errors and dissipation in the work process are prevented by the implementation of systematic approach and teamwork.

\section{Literature Review}

Many examples of the implementation of Lean production in large enterprises can be found in professional and academically literature, while there is very little literature available on the implementation of Lean concept in SMEs. Only a few authors, such as Achanga et al., White and Conner, recommended the implementation of Lean production in SMEs [1-3]. Most often, management in SMEs is not sure of the results of the implementation of Lean concepts or is not able to invest money in the Lean concept. Studies have shown that SMEs, which adopted the Lean concept, have benefitted through increased competitiveness, faster development of innovations, shorter production cycle, increased flexibility and reduced expenses [4].

However, a large number of authors believe that the introduction of Lean concepts or the implementation of tools and methods to improve productivity conceals only certain problems [5-8] in enterprises' business. For this reason, Hayes [9] argues that the successful realisation of the Lean concept in SMEs requires correct planning before implementation to avoid certain difficulties and problems.

In a study from 2007, Baker and McInturff [10] presented their observations during their visits to a certain number of industrial plants in Southern California where they had conversations with business owners. The authors have emphasised that the small companies are more competitive than the large enterprises, but they continue to face competition, tax burdens, ecological regulations and so on. In such circumstances, the Lean concept can affect small businesses to reduce operating costs and increase productivity. Several research were carried out aiming to get answers to the questions: why don't most SMEs today apply Lean methods? and where do managers of SMEs see difficulties in the implementation of Lean methods?

The results of the research of available literature [11] are as follows:

- Lean methods are not well-known in many companies.

- Companies often try to increase the efficiency of production through the large series that minimises the capacity of machines. 
- Lean thinking, if it exists, is applied only in the process of production.

- There is a lack of knowledge in employees and management education.

- Small companies rarely employ qualified workers and there is a necessity of transferring knowledge in small businesses.

\section{Implementation of Lean Concept in SMEs}

In a Lean enterprise, noncompliance is seen as an opportunity for improvement and not just something that needs to be identified and eliminated in the work processes. It is an endless journey for perfection through the continuous improvement of the work process. It is carried out through the constant pursuit and implementation of better ways of performing the process in relation to the way it was previously used by Ohno in 1988 and Grasso in 2005. In industrial systems, the Lean concept is based on designing a workflow that is applicable, flexible, consistent and sustainable in space and time [12].

The word Lean is of English origin and it means thin, slim and slender. The term Lean is used to mark a modern and successful business philosophy, or a world-class organisation characteristic of contemporary business. The goal of this philosophy is to enable the company to achieve a satisfactory market position, in the conditions of turbulent competition, the decline in customer loyalty, constant technological innovations, short product lifespan, and so on. For the implementation of Lean concepts in production systems, the necessary abilities have to be developed to give priority to Lean behaviour and Lean thinking. The basic preconditions for creating an environment for the application of the Lean concept are as follows:

- Lean behaviour of management structure and

- Lean thinking of management structure and other employees.

Lean thinking can be described as the ability of people to make effective and efficient solutions that provide profit to organisation and satisfaction to employees and customers. It provides the ability to determine and define activities that create value, to manage them continuously and to perform those activities daily on a more cost-effective and efficient basis. The implementation of Lean production aims to respond the demands of the customers with less human effort, inventory and time and to develop the desired product, that is, to produce a product of superior quality in the most efficient and cost-effective way [13].

Permanent changes in the environment in which companies operate and the trends of the 21st century imposed the need for design/redesign of business systems. These changes have led to further changes of influential factors and requirements based on which the organisations are designed.

Lean thinking can be described as the ability of people to achieve effective solutions that provide a profit to the organisation as well as the satisfaction to employees and consumers. It provides the ability to define all activities that add value to the product from the user's perspective [14]. The Lean concept is a developed model of production management in the context of improving the quality and engineering processes, which performs a process of reorganisation by identifying the following five principles [15]:

1. Defining the value of the product to the customer,

2. Determining the value of the currents,

3. Creating the value of the currents,

4. Implementation of the "pulling" principle and

5. Striving for perfection.

Lean production is a set of methods and techniques that aim to largely reduce any losses occurring during the process of production and during all other processes in the company. These five principles lead to the understanding of Lean philosophy in companies, and their joint application in all processes of the production system can significantly improve the efficiency of the same. To implement the Lean concept, to adopt a new behaviour - Lean behaviour and a new way of thinking - Lean thinking, ability and will are required. This way the manpower is being developed and training for the use of Lean tools and methods is necessary 
for achieving the defined goals of the business system [15].

At the beginning of the 21st century, the application of Lean principles has had a significant impact on many manufacturing companies. Based on the statistics and analysis of the economic importance of SMEs, it can be observed that they are more numerous and generate a significant portion of the total value in the business economy. In economic theory, there is a series of advantages for SMEs compared with large enterprises. SMEs are flexible in terms of products and adapting to the changes in the market. It is up to the managers of SMEs to correctly understand the change process and the application of appropriate skills and techniques to constantly increase the efficiency and effectiveness of the organisation. To survive and to improve their businesses, use of modern tools and quality techniques, as well as concepts and methodology in the management of business systems, is required.

For this reason, at the beginning of the 21st century, SMEs are the subject of research of many authors in their scientific work. The solution to the current crisis is not only of economic importance but also of social and human importance, which requires a radical change of consciousness and this can be achieved by implementing Lean concepts in SMEs.

Based on the data from the Agency for Statistics, B\&H has ended the first half of 2017 with 35,710 registered companies, of which $74.7 \%$ are micro-enterprises, $18.3 \%$ are small enterprises, $6.0 \%$ are medium-sized and only $1 \%$ are large enterprises, which employ more than 250 workers.

Implementation of Lean concepts in SMEs is one of the ways to increase productivity and competitiveness. After the decision to realise Lean principles in SMEs, managers come up with better results in a very short period of time comparing with what could be achieved in large enterprises. SMEs are more flexible and faster in the implementation of changes due to less bureaucracy and shorter communication links. On the other hand, SMEs are faced with several internal weaknesses and limitations, such as low level of knowledge about new technologies, access to finance, low bargaining power, low productivity, lack of entrepreneurial skills and

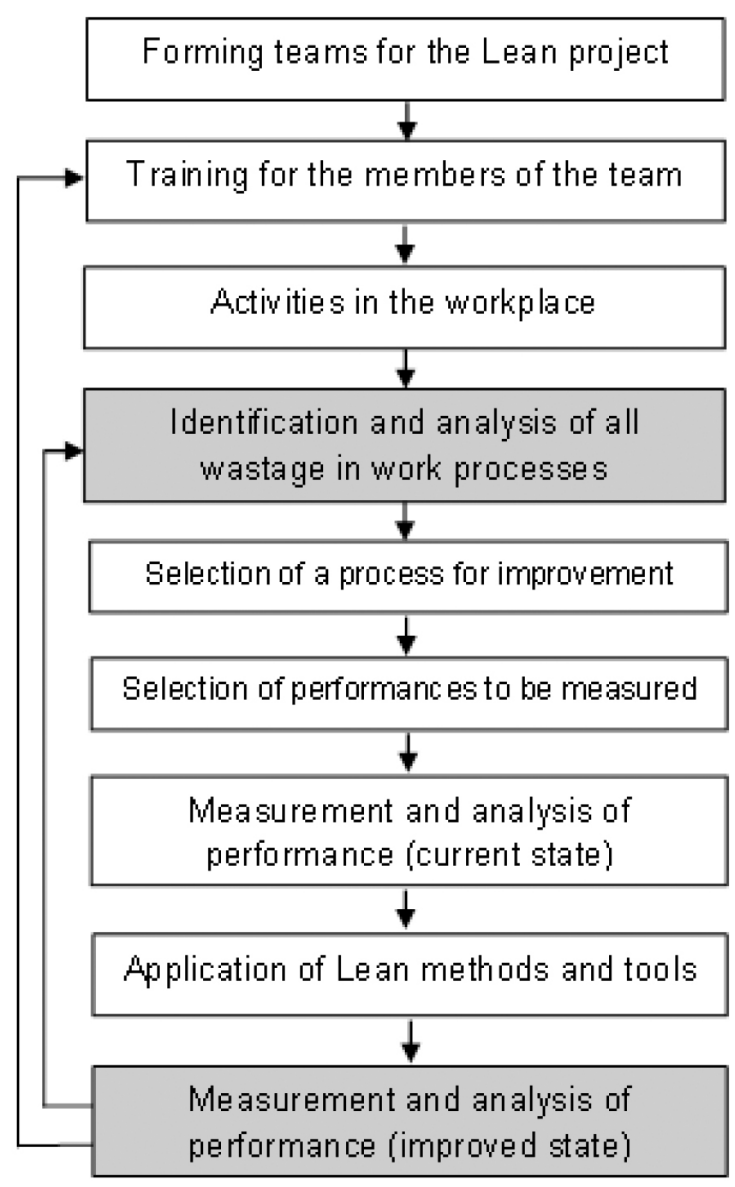

Figure 1: Model for the implementation of the Lean concept in SMEs [17].

lack of knowledge regarding the proper management of human resources.

Aside from the Lean concept, in practice, there are different approaches to creating value in the process of the realisation of the product, such as "pull" manufacturing, total productive maintenance, standardised operation, quality management and so on [16].

Keeping in mind that the availability of material, human and financial resources of SMEs is much lower than that of large enterprises, any additional expense or hiring people for the implementation of the Lean concept has to be planned in detail. Based on these facts, Figure 1 presents the model for the implementation of Lean concepts in SMEs. Beginning of the implementation of Lean concept in SMEs starts with the decision of top management teams to form and implement training for all employees, 
which is usually organised by outside consultants [17].

The team should consist of employees from all organisational units (sectors) who will be the first to adopt a new way of thinking, which is Lean business culture. The training should be organised in such a way that as little additional burden is placed on the employees and to make it easier for them to operate in the workplace []. The main objective of the training is to introduce employees with certain methods and tools that will enable them to recognise and see the wastage in their work processes, and to understand the distinction between activities that add value and those that do not add value to the product. The tools that are commonly used by all employees in their daily work are priority matrix, mapping the value stream, the cause and effect diagrams, analysis of five-why and so on.

After successfully completing the training, an identification of a process for improvement is conducted. The emphasis is on finding ways to improve the process so as to enable a quick return on investment for the implementation of the improvement process. This step can be considered as one of the main drivers for the adoption and implementation of Lean principles by the owners and/or managers of companies [16].

Based on the selection of the improvement process, problems are defined and the causes of the problems are identified, after which actions to eliminate the cause or wastage are taken and specific strategies to minimize the wastage are proposed. Also, it is necessary to generate measurable parameters for monitoring the performance of certain processes of the current state, implementation of the improvement methods and monitoring of an improved state.

\section{Lean Methods and Tools in Medium Enterprises}

The Lean concept includes a set of principles, methods, techniques and tools that emphasise the identification and elimination of all activities that do not add value, that is, eliminating dissipation from the workflow process in business systems. This develops and empowers human resources to use the Lean tools and methods necessary to achieve the functions of the production system's goal and its pursuit of perfection (Figure 2).

\section{Kaizen}

Kaizen is a term composed of two Japanese words: kai (change) and zen (to good), which would mean in free translation - continuous improvement. It represents the way of managing a company focussed on continuous improvement and philosophy according to which every aspect of life should be constantly improved. As the words themselves state, it is necessary to isolate the problem first, then analyse, solve it and ultimately implement the solution. Kaizen is based on the teachings of Edward Deming and his PDCA cycle. Kaizen is a continuous improvement method to be applied by all employees in the company. The result of Kaizen activities is the tools, Poka Yoke, Jidoka, Smed, balancing the production process and so on. Poka Yoke is created by the implementation of Kaizen activities, solving a particular cause of problems in the work processes. Kaizen activities should be carefully prepared, effectively managed and implemented if successful results are sought. The time of the Kaizen event can be divided into three major units: $40 \%$ of the time should be spent on preparation (problem isolation and statistical analysis), $40 \%$ on finding solutions and $20 \%$ on the implementation of the solution [19].

In the company, the application of Kaizen is shown in the assembly process, where the product cable laying is made. The cable laying was made using a template drawing, indicating which hardware was embedded in the product and the device coupling scheme.

The cables were made in accordance with the template, where the template was placed on the desk and ergonomically was not suitable, that is, it was not sufficiently mobile and flexible. The biggest problem was a large number of different wires that were used, but they did not have their stand and place on the desk. Hence, the wires should have been pre-prepared with certain lengths to be tied to the table, which took a long time.

Figure 3 shows a work desk that has been improved in relation to the existing one and the 


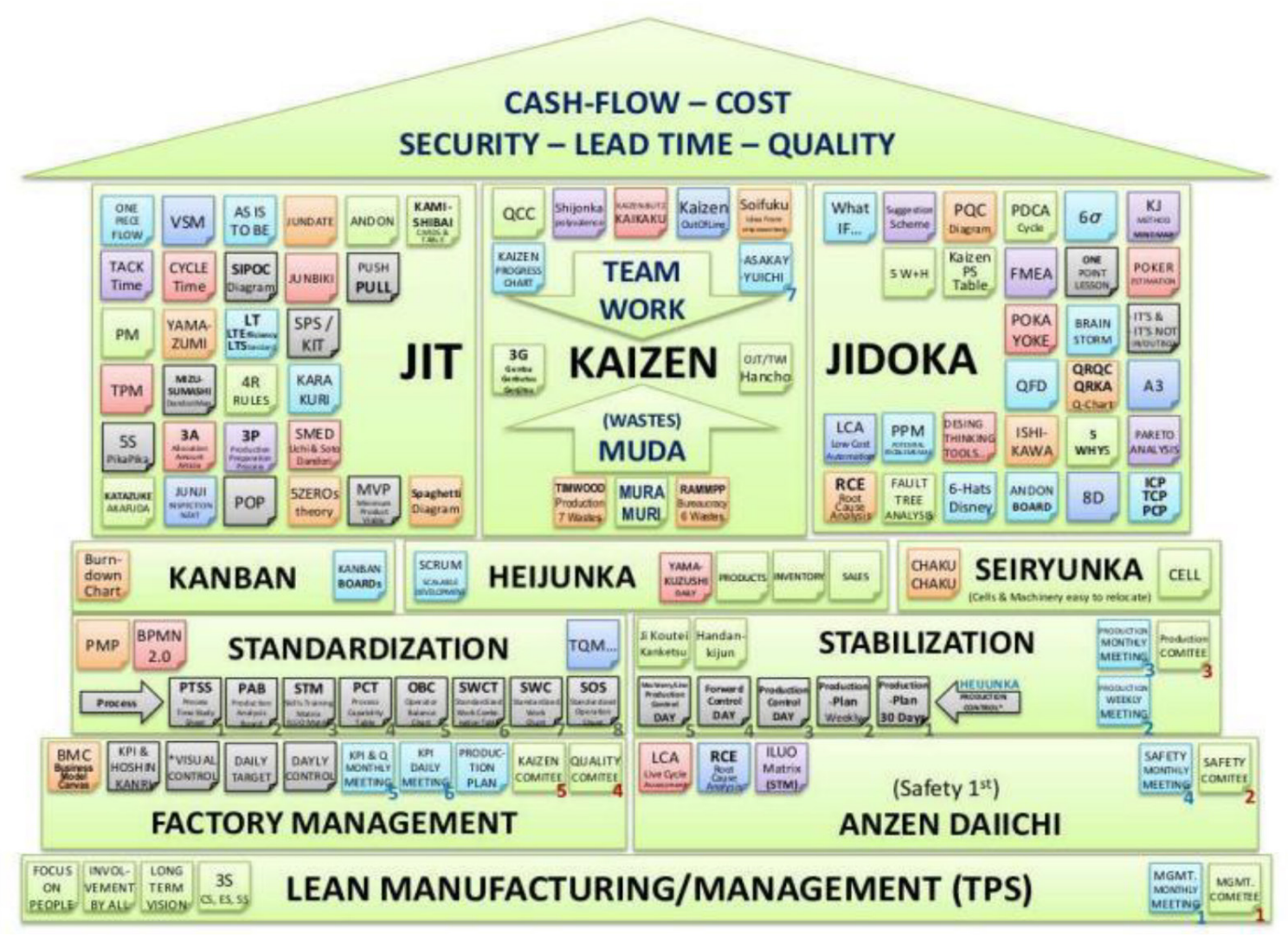

Figure 2: Lean concept - methods and tools [18].
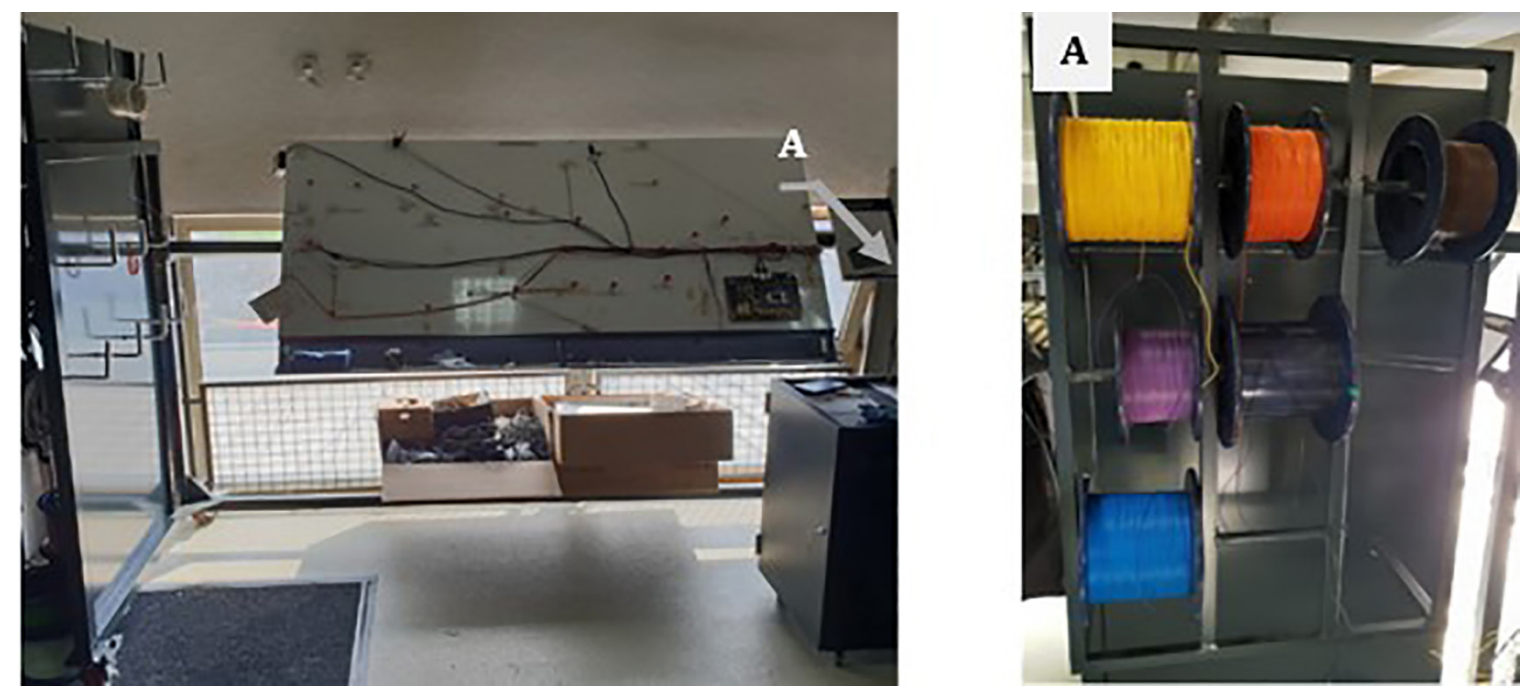

Figure 3: Improvement of working table for assembling cable [19].

team facilitates and accelerates the work on the processes of making cable laying for the products.
On the left side of the table are hooks for connectors, and in the middle there is a template for cables that can be changed because each 
product requires another cable. Below the table, there is a toolbox and there are wheels for making it easier to transport. On the right side, there are carriers of different wires that pass through the right panel and are directly placed on the template.

\section{Poka Yoke}

Poka Yoke has a great application for parts that are welded in the metal industry. Regardless of what is indicated on the workshop drawing, it often happens that the left and right sides are incorrectly welded. These errors are usually detected too late or when the product enters the final stage. This requires the product to return to the initial stage. To prevent these errors, the parts which are welded into the circuit have a "hole slot". By adding hole slot, we enable assembly of two parts in only one way. Figure 4 shows an example of three parts that are welded into one circuit, and it is possible to fit them in only one way [20].
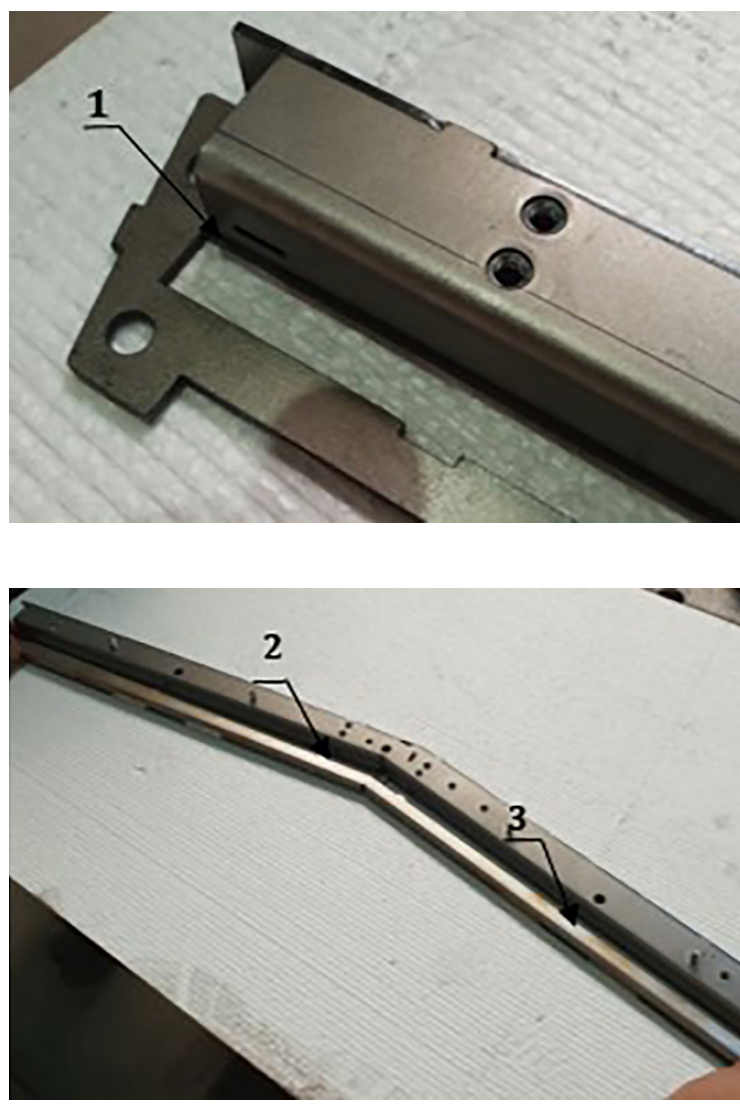

Figure 4: Poke Yoke-application.

\section{Kanban}

The company uses a Kanban board for better communication between the sales and the development, and technical bureaus on projects take place through an electronic cannon table. The company works simultaneously on 10-15 projects, and it was very complicated to conduct and keep track of projects before the introduction of the electronic Kanban board. Kanban board enables engineers to receive project assignments, instructions, deadlines and all other necessary information for their work on their orders (Figure 5).

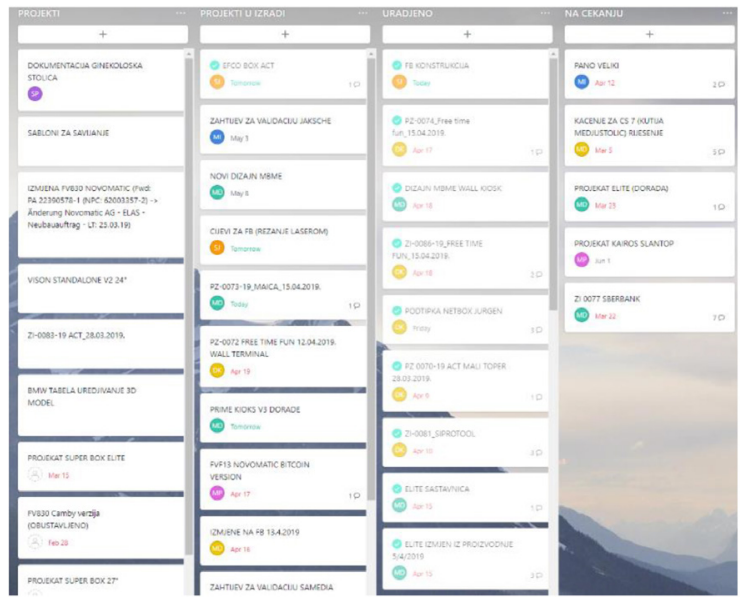

Figure 5: Electronic Kanban board [19].

\section{Discussion and Conclusion}

Available literature and data on the number of registered enterprises indicate that SMEs support the national economy, but the application of Lean practices and its success in these companies are very little explored. In this regard, the above studies indicate resource limitations in SMEs that put them at a disadvantage when it comes to the adoption and implementation of Lean principles and methods. Given the limitations, a strategy is proposed for implementing Lean concepts in SMEs. The concept includes the formation of different teams of employees, training by outside consultants, researching ways to improve processes and elimination of waste. The project of implementation of Lean concept in SMEs begins with activities that do not require large investments and large ex- 
penses, but perseverance and commitment of all employees from top management to operational workers.

The basic preconditions for the proposed model for the application of Lean concept in SMEs can be shown through

- necessity to adopt the Lean way of thinking by investors and top managements in SMEs, even in micro-enterprises, to spread the culture of continuous improvement;

- willingness of management to involve all employees in training at the cost of halted production due to the limited number of employees in SMEs;

- monitoring and analysis of all wastes in all work processes and

- investment in the Lean project with an estimated amount of savings based on the minimisation of waste in the company and return on investment.

For the purpose of research, it is necessary to conduct additional studies on the implementation of Lean concepts and challenges of implementing Lean principles and culture in SMEs. The implementation of Poke Yoke in the welding department has prevented the incorrect welding of the parts and the possibility of errors has been reduced. The Kanban electronic board, which is used in the technical bureau, made it possible to make a clear overview of the active projects and planned tasks, which resulted in increased flexibility and efficiency of operations.

Based on the above examples, it can be concluded that the use of certain Lean tools in SMEs has affected the reduction of total time in certain activities and thus increased the efficiency of the realisation of the planned operations. Finally, it should be noted that all departments in the enterprise (production and administration) can influence the reduction of losses and dissipation in their processes by applying Lean methods and techniques.

\section{References}

[1] Achanga, P., Shehab, E., Roy, R., Nelder, G. (2005): Critical success factors for lean implementation within SMEs. Journal of Manufacturing Technology Management, 17(4), pp. 460-471.

[2] White, R.E. (1999): An empirical assessment of JIT in US manufacturers. Production \& Inventory Management Journal, 34(2), pp. 38-42.

[3] Conner, G. (2001). Lean Manufacturing for the Small Shop. Society of Manufacturing Engineers, 1. edition, Dearborn, MI, 275 p.

[4] Meredith, J. (1987): The strategic advantages of new manufacturing technologies for small firms. Strategic Manufacturing Journal, 8, pp. 249-258.

[5] Denton, P.D., Hodgson, A. (1997): Implementing strategy-led BPR in a small manufacturing company. In: Proceedings of the Fifth International Conference on FACTORY 2000 - The Technology Exploitation Process Conference Publication. Venue Churchill College, Cambridge, UK, pp. 1-8.

[6] Safayeni, F., Purdy, L., Van Engelen, R., Pal, S. (1991): Difficulties of just-in-time implementation. International Journal of Operations \& Production Management, 2(7), pp. 27-36.

[7] Hanga, P., Taratoukhine, V., Roy, R., Nelder, G. (2004): The application of lean manufacturing within small and medium sized enterprises. In: Proceedings of International Conference on Manufacturing Research, Sheffield Hallam University, Sheffield.

[8] Achanga, P., Shehab, E., Roy, R., Nelder, G. (2005): Lean manufacturing to improve cost effectiveness of SMEs. In: Proceedings of the 7th International Conference on Stimulating Manufacturing Excellence in SMEs, University of Strathclyde, Glasgow.

[9] Assessing for lean six sigma implementation and success [online]. Six Sigma Advantage, 2000 [cited 10/10/2005]. Available on: http:// software.isixsigma.com.

[10] Baker, J., McInturff, P. (2007): Small shop dynamics: time and technology. Communications of the IIMA, California, 7(3), pp. 109-118.

[11] Matt, D.T., Rauch E. (2013): Implementation of Lean Production in small sized Enterprises, 8th CIRP Conference on Intelligent Computation in Manufacturing Engineering.

[12] James, J., Frederick, M. (2001): The Lean Company Making The Right Choices, Society of Manufacturing Engineers, Dearborn, Michigan.

[13] Smith, R., Hawkins, B. (2004). Lean Maintenance, Elsevier Inc., Oxford, 278 p.

[14] Tanasić, T., Kosec, B., Janjić G., Soković M. (2014): LEAN and LCA - system approach, ETIKUM 2014, Novi Sad. 
[15] Womack, J.P., Jones, D.T. (1996). Lean Thinking, Simon \& Schuster, New York, $350 \mathrm{p}$.

[16] Doolen, T., Hacker, M. (2005): A Review of Lean Assessment in Organizations: An exploratory study of lean practices by electronics manufacturers. Journal of Manufacturing Systems, 24(1), pp. 55-67.

[17] Martić, R., Tanasić, Z., Janjić, G. (2017): Implementation of LEAN Concept in SMEs. In: 13th International Conference on Accomplishments in Mechanical and Industrial Engineering - DEMI 2017, Banja Luka, 26-27 May 2017, pp. 773-778.

[18] The Structure of Lean Manufacturing \& Lean Management: All tools and concepts [online]. The house of lean, [cited 4/10/2019]. Available on: https:// www.slideshare.net.

[19] Tanasić, Z., Petković S., Janjić, G., Kosec, B. (2019): Application of Lean concept in the ELAS Metalexpert company. In: 14th International Conference on Accomplishments in Mechanical and Industrial Engineering - DEMI 2019, Banja Luka, 24-25 May 2019, pp. 597-603.

[20] Tanasić, Z., Janjić, G., Bobrek, M., (2016). Organizacija i menadžment, University of Banja Luka, Faculty of Mechanical Engineering. 